\title{
HOW CAN I MATE WITHOUT AN APPENDIX MASCULINA? THE CASE OF SPHAEROMA TEREBRANS BATE, 1866 (ISOPODA, SPHAEROMATIDAE)
}

BY

\section{GIUSEPPE MESSANA ${ }^{1}$ )}

CNR-Istituto per lo Studio degli Ecosistemi, Via Madonna del Piano, I-50019 Sesto Fiorentino, Firenze, Italy

\begin{abstract}
Several hours mating behaviour of the woodborer isopod, Sphaeroma terebrans were recorded using a video camera. S. terebrans, the only species in the genus to lack an appendix masculina, has a peculiar way of mating that is completely different from that in other Isopoda. Instead of introducing the sperm into the genital opening of the female, the male releases it into the water current created by the beating of the female pleopods. The origin of this adaptation is discussed.
\end{abstract}

\section{RIASSUNTO}

Il comportamento sessuale dell'isopode Sphaeroma terebrans, è stato filmato per diverse ore, attraverso una telecamera. S. terebrans, l'unica specie del genere ad essere sprovvista di una appendix masculina, ha un modo di accoppiarsi del tutto particolare che è completamente differente da quello degli altri isopodi. Il maschio invece di introdurre lo sperma nella apertura genitale femminile, lo rilascia nella corrente d'acqua creata dal battito dei pleopodi. L'origine di questo adattamento viene discussa.

\section{INTRODUCTION}

Isopods colonize almost every environment on earth, from deep seas to desert mountains. Their long evolutionary history, the first fossil dating from the Carboniferous (Schram, 1986), has led to great morphological variety. Despite such a wide diversity of morphotypes, the species share a common character: a copulatory organ, constituted by a modified endopod of the male pleopod II (Brusca \& Wilson, 1991). The appendix masculina (= male stylet) is used to transfer sperm to the female during mating. It may be very simple, as in most marine isopods,

1) e-mail: messana@ise.cnr.it

(C) Koninklijke Brill NV, Leiden, 2004

Also available online: www.brill.nl 
or a very complex structure, as in several Asellota (cf. Magniez \& Henry, 1970; Wilson, 1991).

The Sphaeromatidae are marine and intertidal isopods widely distributed throughout the world, from the intertidal to a depth of a little more than $1000 \mathrm{~m}$. They have also colonized freshwater and subterranean ecosystems. Some species practise mate guarding (Ridley, 1983; Shuster, 1991; Jormalainen \& Shuster, 1999). The males usually possess a simple appendix masculina of variable length.

The species Sphaeroma terebrans Bate, 1866 is a woodborer distributed in tropical and subtropical areas. It shows a preference, at least in the Philippines and Kenya, for the aerial roots of unexposed mangrove woods (pers. obs.), especially of the genus Rhizophora, but it can be found in any kind of live and rotting wood. It excavates burrows that have almost the same diameter as its body. Females remain within their burrow, apparently throughout their life, where they take care of their offspring (Messana et al., 1994; Thiel, 1999; 2001).

Unlike all other species of the genus, $S$. terebrans lacks an appendix masculina (Harrison \& Holdich, 1984; Harrison \& Ellis, 1991). The absence of an appendix masculina, the apparent absence of males in open waters, and the fact that $S$. terebrans practises precopulatory mate guarding (pers. obs.) prompted investigation of its mating behaviour.

\section{MATERIALS AND METHODS}

Aerial roots of Rhizophora with evident Sphaeroma burrows were collected in Mtwapa Creek (Mombasa, Kenya) and brought to the Kenyan Marine and Freshwater Research Institute (K.M.F.R.I.) in Mombasa. Pieces of root were cut longitudinally with adequate care, to expose the Sphaeroma holes, and were then covered with microscope slides to permit video recording without unduly disturbing the specimens. The treated pieces of root were suspended along the walls of an aquarium where seawater was kept running (fig. 1). Males were marked with a white spot on the pleotelson. The behaviour of several individuals of the species from the Kenyan mangrove forest was observed through a video camera with macro lenses in the K.M.F.R.I. laboratory in Mombasa and later in the laboratory of the Centro di Studio per la Faunistica ed Ecologia Tropicali of the CNR in Florence, Italy.

\section{RESULTS}

Females of Sphaeroma terebrans spend most of the time in their burrows, which are rarely abandoned once dug. They actively and continuously dig in the 


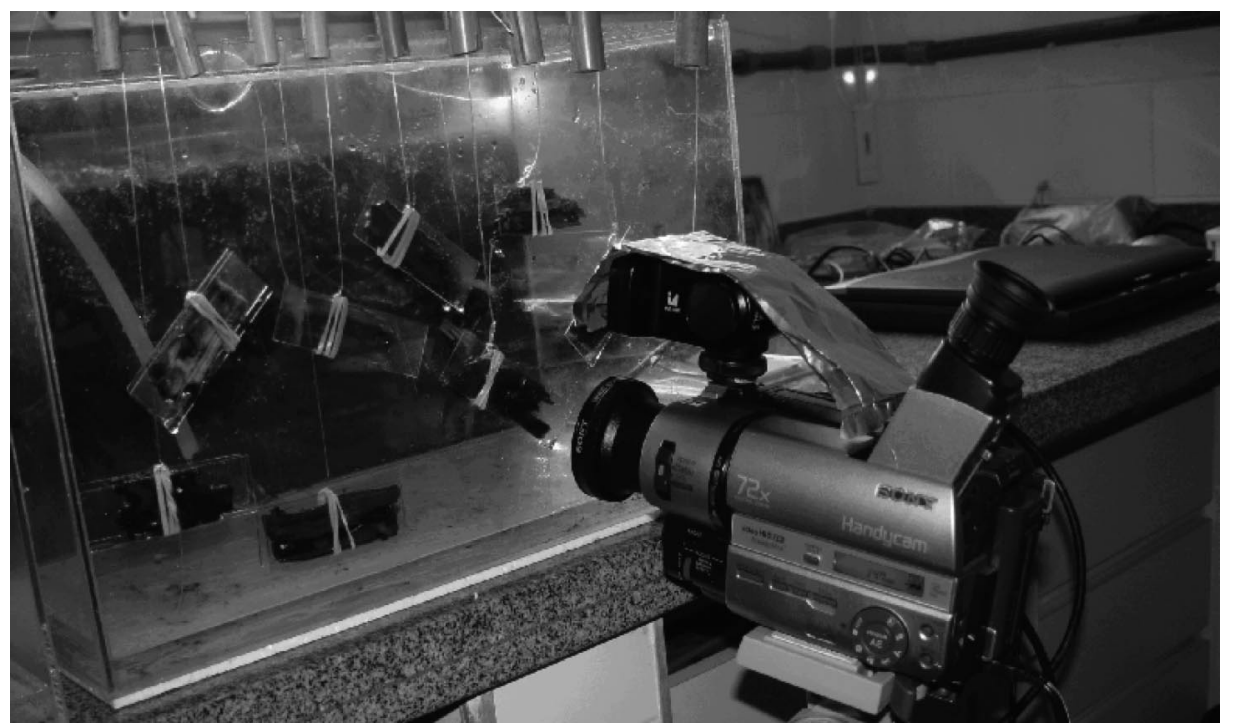

Fig. 1. Experimental set up for video recording. Several pieces of root are suspended along the wall of an aquarium.

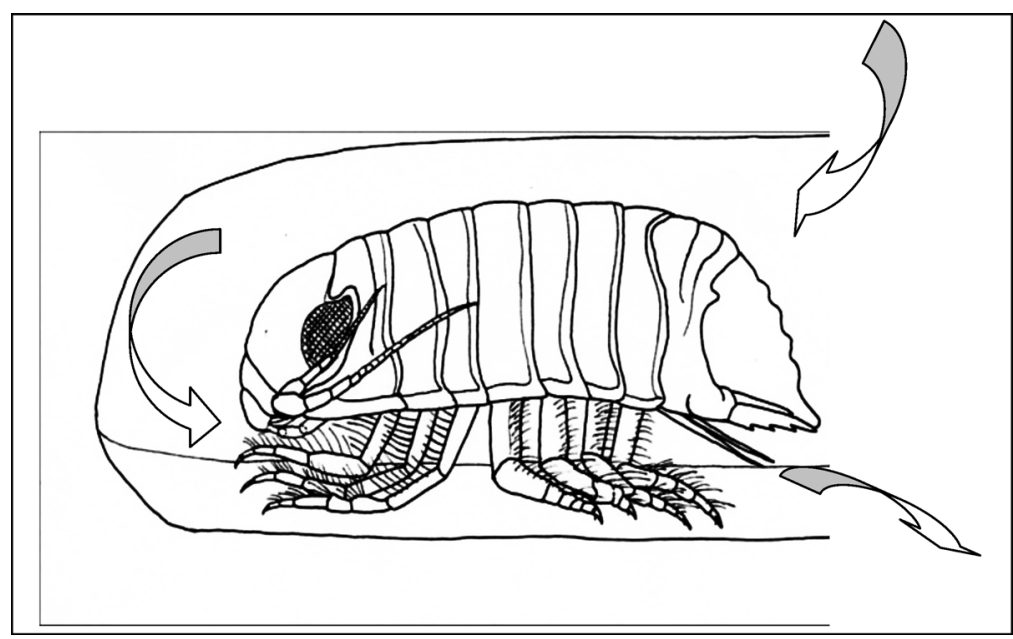

Fig. 2. Water current inside the Sphaeroma terebrans Bate, 1866 hole. Arrows indicate the circulation of water.

mangrove's aerial roots. They feed on suspended organic matter and micro algae by beating their pleopods to create the current necessary to bring food inside the hole (fig. 2) (John, 1968; Rotramel, 1975; Estevez, 1978). This current is also important for waste removal, water exchange, and, as will be shown, mating. The females take care of their offspring and prevent them from leaving the hole, at least in the 


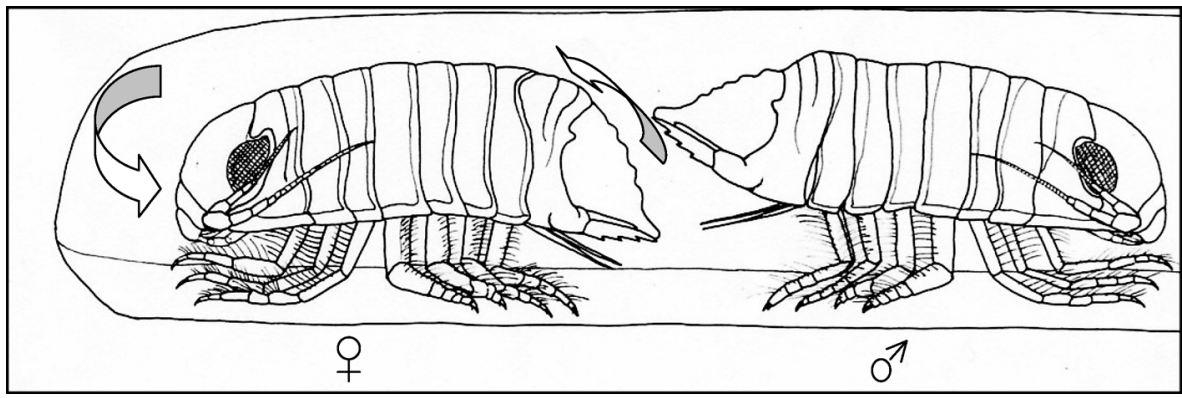

Fig. 3. Sphaeroma terebrans Bate, 1866 mating: the male raises his pleotelson and releases sperm (in the form of a spermatophore) into the water current.

first few days after they leave the brood pouch (Messana et al., 1994; Thiel, 2001). They actively defend their hole using the pointed uropods as a weapon (pers. obs.).

In the laboratory, males can be observed swimming around or inside the external part of a female's burrow, often trying to mate, or remaining on the outer part of the hole where they remain for several days, possibly practising mate guarding (Dunham \& Hurshman, 1991).

The size of the burrow and the fact that females are rarely found outside the burrow has led to a unique way of mating, which I was fortunate enough to film in a single pair during several hours of observation.

The male, head in, stays in the most external part of the burrow occupied by the female and begins a series of movements as if trying to go deeper into the hole. The female actively tries to expel him with several flicks of her pointed uropods. These attempts to expel the male diminish in intensity and stop completely some time after he begins a series of peristaltic movements of the entire body. In the single individual I was able to observe, these movements lasted up to two hours. At a certain point, the male turns head out, bends up his pleotelson (fig. 3) and emits a small whitish mass from his abdomen, probably a spermatophore. The whitish mass is drawn into the burrow by the water current created by the beating of the female's pleopods until it disappears completely under her abdomen. After a few seconds, the male leaves the hole where he had been for several days and does not return.

\section{DISCUSSION}

Among other sphaeromatid species investigated in detail, such as Paracerceis sculpta (Holmes, 1904) (cf. Shuster, 1987, 1991) and Dynamene bidentata (Adams, 1800) (Holdich, 1968, 1970), only Sphaeroma terebrans presents the mating behaviour described above. 
In fact, the male of $S$. terebrans faces a difficult situation: the female's burrow is not much larger than her diameter and the dangerous "flicks" with which she protects her hole give the male no chance to mate in a conventional way, i.e., by using an appendix masculina to transfer sperm to the female's genital opening. This situation might have produced, in some ancestral individuals, this "unconventional" (Shuster 2002: 688) male mating behaviour, which was apparently passed on to offspring and successively fixed in the entire lineage.

Like many intertidal animals, $S$. terebrans is well adapted to this harsh but predictable environment, being able to survive long periods of drought (pers. obs.). The result is a presumably $K$-reproductive strategy, with the number of eggs varying from 20 to 80 (Thiel, 1999; and pers. obs.). The male of this taxon has adopted a way of releasing sperm, similar to that of marine taxa with an $r$-strategy. We don't know yet if internal insemination, considered one of the most advantageous adaptations of the order (Ridley, 1983), is lost in S. terebrans, like the male appendix masculina, or not. Probably it is: Wilson (1991) in fact suspected that those isopods devoid of a spermatheca such as Sphaeroma, might not practise internal insemination.

The lack of an appendix masculina is rare in Isopoda (cf. Harrison \& Ellis, 1991). Holdich (1968: 152) stated: "Recorded examples are Dynamene, Ancinus and Dynameniscus and it is not known how copulation is effected in these forms". The monospecific genus Dynameniscus is not devoid of an appendix masculina (Kensley \& Bruce, 2001) nor are some species of Ancinus (cf. Kensley \& Schotte, 1987; Pires, 1987). Dynamene bidentata, most thoroughly investigated by Holdich (1968, 1970), is intertidal and occupies rock crevices, dead barnacle shells, coral, and sponges during the reproductive period, with one male guarding a harem of several females.

It would be interesting to investigate this seemingly evolutionary "cul de sac" in more detail, in order to clarify the causes that led to these similar morphological adaptations, and to see if there is any difference between the mating behaviour of Dynamene bidentata and Sphaeroma terebrans.

\section{ACKNOWLEDGEMENTS}

The author is indebted to Prof. E. N. Okemwa, former Director of the Kenyan Marine Fisheries Laboratory in Mombassa, who hosted him during this research. Thanks are due also to Niel Bruce of the National Institute of Water and Atmospheric Research (Wellington, New Zealand) who critically reviewed the manuscript. Deborah Benvenuti kindly prepared the accurate China ink drawings. Some of the results were presented as an oral communication at the Mombasa Meeting on Mangrove Macrobenthos in 2000. 


\section{REFERENCES}

BrusCA, R. C. \& G. D. F. Wilson, 1991. A phylogenetic analysis of the Isopoda with some classificatory recommendations. Mem. Queensland Mus., 31: 143-204.

Dunham, P. J. \& A. M. Hurshman, 1991. Precopulatory mate guarding in aquatic Crustacea: Gammarus lawrencianus as a model system. In: R. BAUER \& J. MARTIN (eds.), Crustacean sexual biology: 50-66. (Columbia University Press, New York).

Estevez, E. D., 1978. Ecology of Sphaeroma terebrans Bate, a wood boring isopod in Florida mangrove forest: 1-154. (Ph.D. Thesis, University of South Florida, Tampa).

Harrison, K. \& J. P. Ellis, 1991. The genera of the Sphaeromatidae (Crustacea: Isopoda): a key and distribution list. Invertebr. Taxon., 5: 915-952.

Harrison, K. \& D. M. Holdich, 1984. Hemibranchiate sphaeromatids (Crustacea: Isopoda) from Queensland, Australia, with a world-wide review of the genera discussed. Zool. Journ. Linn. Soc., London, 81: 275-387.

Holdich, D. M., 1968. Reproduction, growth and bionomics of Dynamene bidentata (Crustacea, Isopoda). Proc. zool. Soc., London, 156: 137-153.

— - 1970. The distribution and habitat preferences of the Afro-European species of Dynamene (Crustacea: Isopoda). Journ. nat. Hist., London, 4: 419-438.

JoHn, P. A., 1968. Habits, structure and development of Sphaeroma terebrans (a wood-boring isopod): 1-82, psl. 1-9. (University of Kerala Publications, Trivandrum).

Jormalainen, V. \& M. Shuster, 1999. Female reproductive cycle and sexual conflict over precopulatory mate-guarding in Thermosphaeroma (Crustacea, Isopoda). Ethology, 105: 233246.

Kensley, B. \& N. L. BRUCE, 2001. Redescription of Dynameniscus carinatus (Richardson, 1900) (Crustacea: Isopoda: Sphaeromatidae). Proc. biol. Soc. Washington, 114 (1): 188-196.

Kensley, B. \& M. Schotte, 1987. New records of isopod Crustacea from the Caribbean. Proc. biol. Soc. Washington, 100 (1): 216-247.

Magniez, G. J. \& J. P. Henry, 1970. Sur la structure des pléopodes copulateurs des Aselloidea (Crustacea Isopoda Asellota). C. R. Acad. Sci., Paris, 270: 93-95.

Messana, G., V. Bartolucci, J. Mwaluma \& M. Osore, 1994. Preliminary observations on parental care in Sphaeroma terebrans Bate, 1866 (Isopoda Sphaeromatidae), a mangrove wood borer from Kenya. Ethology, Ecology and Evolution, (Special Issue): 125-129.

PIRES, A. M. S., 1987. The contribution of isopods in the feeding of Sympterygia spp (Pisces: Rajidae) with a description of Ancinus gaucho sp. n. (Isopoda: Sphaeromatidae). Bolm Inst. oceanogr., São Paulo, 35 (2): 115-122.

RIDLEY, M., 1983. The explanation of organic diversity. The comparative method and adaptation for mating: 1-272. (Clarendon Press, Oxford).

Rotramel, G., 1975. Filter feeding by the marine boring isopod Sphaeroma quoyanum H. Milne Edwards, 1840 (Isopoda, Sphaeromatidae). Crustaceana, 28 (1): 7-10.

SCHRAM, F. R., 1986. Crustacea: 1-606. (Oxford University Press, New York, Oxford).

ShUSTER, S. M., 1987. Alternative reproductive behaviors: three discrete male morphs in Paracerceis sculpta. Journ. Crust. Biol., 7 (2): 318-327.

- —, 1991. The ecology of breeding females and the evolution of polygyny in Paracerceis sculpta, a marine isopod crustacean. In: R. BAUER \& J. MARTIN (eds.). Crustacean sexual biology: 91-110. (Columbia University Press, New York).

— —, 2002. Mating strategies, alternative. In: M. PAGEL (ed.), Encyclopedia of evolution, 2: 688, 693. (Oxford University Press, Oxford).

Thiel, M., 1999. Reproductive biology of a wood-boring isopod, Sphaeroma terebrans, with extended parental care. Marine Biology, Berlin, 135: 321-333. 
— - 2001. Parental care behaviour in the wood boring isopod Sphaeroma terebrans. In: B. KENSLEY \& R. C. BRUSCA (eds.), Isopod systematics and evolution. Crustacean Issues, 13: 267276. (A. A. Balkema, Rotterdam).

WiLsON, J. B., 1991. Functional morphology and evolution of isopod genitalia. In: R. BAUER \& J. MARTIN (eds.), Crustacean sexual biology: 228-245. (Columbia University Press, New York). 